\title{
Subjects and Masters: Uyghurs in the Mongol Empire. \\ By Michael C. Brose. Bellingham, WA: Center for East Asian Studies, Western Washington \\ University, 2007. Pp. 348. ISBN I0: 0914584294; I3: 97809I4584292.
}

\section{Reviewed by Dai Matsui, Hirosaki University}

E-mail dmatsui@nifty.com

doi:10.1017/S1479591409000278

By the last quarter of the thirteenth century the empire of Mongol nomads had conquered the whole area of China proper. To assist their rule of China, the Mongols recruited civil officials from peoples of non-Chinese origin. In Chinese sources these people are referred to as 色目人 semuren. From these semuren groups author Michael Brose takes up a few families of Uyghur descent that originated in the Tianshan - the Tarim Basin area of Central Asia. He sets out to portray these Uyghurs as people who enacted a liminal existence, that is, not just as semuren commanders and officials but also, later, as greatly sinicized literati active in China under Mongol rule.

In the Introduction the author defines the Uyghurs in China as a diaspora from Central Asia and states the book's aim to be an examination of their history, especially the factors that enabled their political and cultural success. In Chapter I Brose outlines basic knowledge about the social order of the Mongol Empire, and in Chapter 2 presents a brief history of the Uyghurs from the time of their nomadic empire in Mongolia to the exiled kingdom in the Eastern Tianshan region.

In Chapter 3 the author treats the first generation of the Diaspora Uyghurs, most of whom had been members of the Uyghuristan aristocracy. These people succeeded in maintaining their high status within the Mongol realm by way of their high-level administrative skills, often being appointed as judge (Mong. jaryuči), secretary (bičigči), agent (daruyačı), and so forth. ${ }^{\mathrm{I}}$ After this generation passed away, however, their descendants had to follow other routes to political success. The plight of these descendants may be regarded as the crux of this book, through which emerges the author's unique view on the Diaspora Uyghurs in China.

Chapter 4 picks up two descendent families of the Diaspora Uyghurs, Qara-Ïrač-Buyruq and Buyruq-Qaya, and the manner in which they created simultaneous elite identities. While hereditary advantage gave them a step up in the Mongol aristocracy, in China they were also able to adapt to Chinese modes of administration and thus advance in the civil sphere. The author finds this transformation reflected in the fact that after some generations the Qara-Ï $\gamma$ ač-Buyruq's family observed the Chinese style of naming, adopting the surname Lian 廉.

In Chapters 5 and 6 Brose conducts a detailed analysis of another Uyghur family, headed by Qara-Buqa. He belonged to the second generation of Diaspora Uyghur and was killed while attempting to pacify rebels, an end that ostensibly proved his strong loyalty and fidelity, the most esteemed concepts in Chinese Confucianism. His wife refused levirate marriage, instead opting to protect "her virtue as a chaste widow" and devote herself to giving their children a Confucian-style upbringing. Brose interprets their son Xie Wenzhi 奜文質, who gained renown for his filial piety through the story that he served up a piece of his flesh for his sick mother, as a transitional figure to Chinese-Confucian norms, explaining that he turned to southern China, adopted the Chinese-style surname 侇 Xie, educated his sons in the Confucian tradition, and that successive generations of his family gained appointments solely in the civilian bureaus. Qara-Buqa's loyalty to the Mongol dynasty, his widow's fidelity, and his son's filial piety together comprised a topos (san-jie 三節) symbolizing their shift to Chinese culture.

According to the author, this legacy provided the next generation of the Xie family with "social capital" in the Chinese society of southern China, their new residence, and led to their great success. Chapter 7 depicts six of these family members, who successfully passed through the keju 科舉 civil 
service exam, acquired the jinshi 進士 degree, and established their reputations among the contemporary Chinese literati. The ultimate source of their success, the author argues, was their father's decision to settle in southeast China and the strategy to "secure their futures that would complement their semuren status" within Chinese Confucian culture. In the Conclusion, the author confirms that Uyghur elites "were undoubtedly genuinely attracted to Chinese cultural modes and ways" (p. 266) and tentatively credits that attraction to be the means by which they gained political power as Chinese elite, rather than, as earlier generations had done, serving as adjutants of the Mongols, that is, working as semuren officials.

The book is based on the author's thorough assembly of information about the Uyghurs that is scattered throughout the Yuanshi [The Dynastic History of Yuan] as well as other Chinese sources such as anthologies compiled by contemporaneous Chinese literati and local gazetteers from later periods. The adoption of sociological concepts such as diaspora and social capital should be assessed as a proactive attempt to position the Uyghurs of the Mongol empire in the context of the global history as well as the broader arena of humanities research.

Even so, some questions remain; for the time being I will concentrate on the arguments presented in Chapters 5-7. In order to emphasize the importance of Chinese Confucian culture for the Xie family, the author relies entirely on Chinese sources written by Chinese literati, materials that undoubtedly had a tendency to esteem Chinese-Confucian culture. That being said, even Chinese sources, paradoxically, may suggest that the Uyghurs had shifted to the Chinese tradition to a lesser degree than Brose argues. For example, in their eulogies for the Xie family, Ouyang Xuan's and Xu Youren's references to individual family members each include the surname Xie, except references to one individual, Shanzhu 善著. For eulogies this is unusual, because typically the surname was omitted. In other words, Ouyang and $\mathrm{Xu}$ still recognized their names as non-Chinese (see p. I47, n. II; p. 209, n. II). And rightly so, because we can reconstruct the original forms of these names in Uyghur or Mongolian: Xie Wenzhi <Sävinč, 偰玉立 Xie Yuli < *Sävüglüg Säviglig, 偰直堅 Xie Zhijian<Säcägän, 偰哲篤 Xie Zhedu < * Säčägtü= Čăčägtü, 偰帖該 Xie Tiegai < *Setergei, 偰吉思 Xie Jisi <Särgis=Sergius, 偰百遼遜 Xie Bailiaosun < ${ }^{*}$ Sebeglegsün (?). In contrast with these figures, only Shanzhu was "truly" Chinese. It is also noteworthy that Xie Bailiaosun, his son and his grandsons all emigrated to Koryo 高麗, and achieved success at court through their talent in Uyghur script and Mongolian language. ${ }^{2}$ The existence of these non-Chinese names, together with the above-mentioned historical information, may well indicate that the cultural orientation of the Xie family as Uyghur continued to be more vibrant than the author recognizes. In other words, the author's self-declared focus on how "Uyghurs became part of the Chinese social fabric" (p. I8) may be so single-minded that he has overlooked how factors that were non-Chinese - Uyghur or Mongolian - might have affected later generations of the Xie family.

Although the author spends little time with the Old Uyghur materials unearthed from the Turfan region, to some degree they too can supplement his arguments. For example, a fragment of the Uyghur Buddhist sutra from Turfan (printed in Hangzhou 杭州 around I297 to 1307) suggests close cultural ties between the Uyghurs in southeastern China and their homeland. 3 Also, a correction is necessary of the author's discussion on p. 87: the question about the origin of the technology of seals transferred to the Mongols by Tatar Tongga ${ }^{4}$ is easily solved by reviewing the many examples of seals with Chinese inscription stamped on Uyghur documents from Turfan. These clearly display that the Uyghurs had already accepted the technology of seals from the Chinese in the

2 Miya Noriko 宮紀子, in Nairiku Ajia gengo no kenkyū 内陸アジア言語の研究 [Studies on the Inner Asian Languages] ig (2004), pp. I77-79.

3 Ogawa Kanji 小川貫式, in Indogaku Bukkyōgaku kenkyū 印度學佛教學研究 [Journal of Indian and Buddhist Studies] 4:I (I956), p. 35 . 
Turfan Basin. ${ }^{5}$ One might add that to a certain degree Uyghurs inherited the administrative systems brought by the Tang Dynasty to Turfan. ${ }^{6}$ Also, the city Solmï, identified by the author as Sayram (p. Ioo), is actually a Turkic name for 焉耆 Yanqi (= Qarašahr). ${ }^{7}$

It was regrettable to find quite a few misunderstandings of historical fact and misinterpretations of Chinese texts, examples being: (p. 66) the Uyghur kingdom of 甘州 Ganzhou was in fact conquered by the Xixia 西夏 Kingdom; (p. 70) the Uyghur Empire did defeat the Tibetans at Beiting around 790 $\mathrm{AD}$ to put the Tianshan area including Gaochang under their control until their westward migration; the author's translation of a sentence from Dashi’s biography, 有謀略, 爲國人所信服 as, “Dashi had a plan to make his fellow countrymen submit [to the Mongols]" (p. 86) should be corrected to "Possessing rich wisdom and strategies, Dashi had been trusted by the countrymen”; (p. I Io) Liaowang 遼王, whom Sergius 撒吉斯 served as a tutor, was not a Qara-Qitay king but Temüge-Otčigin, whose descendants were given the title Liaowang; (p. 174) the author's translation of a phrase from Qara-Buqa's eulogy, 少有志, as “[Qara-Buqa] has seldom been written about” should be corrected into “[Qara-Buqa] was highspirited in his boyhood", and 延祐設科今六舉, 公六孫舉輶中一人 should be rendered as "since the civil-service exam system was established in the Yanyou era until now the exam has been carried out six times, and in every exam one of his six grandsons passed"; and Gan-er-han 幹耳汗 is a typo for wo-er-han 斡耳汗< Mong. Orqon “the Orkhon River" (p. I87). Even though most of these oversights are not serious, collectively they might reduce the reliability of the work.

The author also might have benefitted from referring to a work by Umemura Hiroshi ${ }^{9}$ and a recent one by Hsiao Ch'i-ch'ing. ${ }^{\circ}$ Umemura clarifies the marital connections between the Uyghur families, suggesting they made efforts to retain Uyghur identity. Hsiao treats many more semuren families whose members attained the jinshi degree while introducing their cultural background.

Contrary to the author's modest self-declaration that his volume is merely a case study, in fact it abounds with intriguing arguments. I expect that it will draw a response from researchers working in a variety of disciplines such as the cultural history of the Turkic, Mongolian and Chinese peoples, diaspora studies, and sociology.

Situating the Uyghurs Between China and Central Asia.

By Ildikó Bellér-Hann, M. Cristina Cesàro, Rachel Harris and Joanne Smith Finley, eds. Aldershot, UK: Ashgate, 2007. Pp. 276. ISBN I0: 07546704I4; I3: 97807546704I4.

Reviewed by Masami Hamada, Kyoto University

E-mail masami.hamada@bun.kyoto-u.ac.jp

doi:10.1017/S147959140900028X

Until the early I980s, Xinjiang/East Turkestan studies were isolated and unpopular, and the number of specialists very limited. The "open-door policy" of China changed that situation drastically. Many

5 See, e.g., Moriyasu Takao, Die Geschichte des uigurischen Manichäismus an der Seidenstraße, Wiesbaden, 2004, pp. I49-5I.

6 Matsui Dai 松井太, in Tulufanxue yanjiu: di er jie Tulufanxue guoji xueshu yantaohui lunwenji 吐魯番學研究: 第 二屆吐魯番學國際學術研討會論文集, Shanghai, 2006, pp. I96-202.

7 Geng Shimin 耿世民 and Zhang Guangda 張廣達, in Lishi yanjiu 歴史研究 I980-2, pp. I47-59.

8 Moriyasu, Geschichte d. uig. Manichäismus, op. cit., pp. 33-34, fn. 94.

9 Umemura Hiroshi 梅村坦, in Y. Nagata and M. Matsubara, eds., Isuramu sekai no hitobito 3: bokuchikumin イス ラム世界の人々 3 ・牧畜民. Tokyo, I984, pp. I09-49.

Io Hsiao Ch’i-ch'ing 蕭啓慶, in Han-hsüeh yan-ch’iu 漢學研究 [Chinese Studies] I8:I (2000), pp. IoI-28. 